Movchan, R., Vozniuk, A., Burak, M., Areshonkov, V., \& Kamensky, D.. (2021). Criminal law counteraction to land pollution in the EU countries: searching for the optimal model. Amazonia Investiga, 10(42), 15-23. https://doi.org/10.34069/AI/2021.42.06.2

\title{
Criminal law counteraction to land pollution in the EU countries: searching for the optimal model
}

\section{Кримінально-правова протидія забрудненню земельних ресурсів в країнах СС: пошук оптимальної моделі}

\author{
Received: May 10, $2021 \quad$ Accepted: June 15, 2021
}

Written by:

Roman Movchan ${ }^{6}$

https://orcid.org/0000-0003-2074-8895

PUBLONS: Web of Science ResearcherID: AAK-1080-2021

Andrii Vozniuk ${ }^{7}$

https://orcid.org/0000-0002-3352-5626

PUBLONS: Web of Science ResearcherID: AAJ-1865-2020

Maria Burak ${ }^{8}$

https://orcid.org/0000-0002-1099-2096

PUBLONS: Web of Science ResearcherID: AAQ-4797-2021

Vitalii Areshonkov ${ }^{9}$

https://orcid.org/0000-0003-1776-1220

PUBLONS: Web of Science ResearcherID: AAN-9659-2021

Dmitriy Kamensky ${ }^{10}$

https://orcid.org/0000-0002-3610-2514

PUBLONS: Web of Science ResearcherID: AAQ-4357-2021

\begin{abstract}
The main goal of the article is to study both advantages and disadvantages of the approaches of the European Union (EU) states to criminal law prevention of land pollution. As a result of this an optimal legislative model should be developed to protect this element of the environment from criminal encroachment, which can be further used by the EU states in improving existing or creating new rules aimed at criminal law protection of land resources from pollution or the creation of new rules aimed at criminal law protection of land resources from pollution. The following research methods have been used to study criminal law provisions of the selected countries, to prove the stated hypotheses and to formulate conclusions: comparative law, system analysis, formal-logical, dialectical and
\end{abstract}

Анотація

Метою статті $є$ вивчення переваг та недоліків підходів окремих країн Свропейського Союзу щодо кримінально-правової протидії забрудненню земель, за результатом якого має бути розроблена оптимальна законодавча модель охорони цього елементу природного середовища від злочинних посягань, яка надалі може бути використана державами Європейського Союзу при удосконаленні вже існуючих або ж створенні нових норм, що направлені на кримінально-правову охорону земельних ресурсів від забруднення. Для дослідження кримінального законодавства обраних країн, доведення висловлених гіпотез, формулювання висновків використано такі наукові методи: порівняльно-правовий, системного аналізу, формально-логічний, діалектичний та метод

\footnotetext{
${ }^{6}$ Doctor of Law, Associate Professor, docent Department of Constitutional, International and Criminal Law Vasyl'Stus Donetsk National University, Ukraine.

${ }^{7}$ Doctor of Law, Professor, Head of the Research Laboratory, National Academy of Internal Affairs, Ukraine.

${ }^{8}$ Candidate of legal sciences, Senior Research Fellow of the Research Laboratory on the Problems of Combating Crime of the National Academy of Internal Affairs, Ukraine.

${ }^{9}$ Doctor of Law, Senior Research Scientist, Leading Researcher of the Research Laboratory on the Problems of Combating Crime of the National Academy of Internal Affairs, Ukraine.

${ }^{10}$ Doctor of Law, Professor, Berdyansk State Pedagogical University, Ukraine.
} 
modeling method. As a result of the study of various models of criminal law protection of land resources embodied in the legislation of nineteen European Union states, it has been proved that: 1) such protection should be carried out by a single universal rule on criminal liability for pollution not only of land but also of other components of the environment (water, air, forest); 2) only such land pollution shall be considered criminal, which has led to real (non-potential) damage to the environment, human health or property damage; 3) liability for land pollution should be differentiated depending on: a) weather guilty person's act was intentional or negligent; b) what the consequences of land pollution have been.

Key words: environment, pollution, land resources, crime, criminal liability.

\section{Introduction}

Today, the ever-growing scale of environmental pollution is one of the greatest global challenges for the sustainable development of humankind. This fully applies to European countries, given that the member states of the European Union (hereinafter - the EU) have in recent years significantly intensified their activities aimed at combating relevant socially dangerous acts, including those related to land resources. The particular urgency of the problem of land protection is explained by the fact that, on the one hand, the soil is a non-renewable resource and a very dynamic system, which performs many functions and provides services vital to human activity and ecosystem survival (Proposal, 2004), and on the other, as recognized by both European and Ukrainian experts, is the fact that most of Europe's lands remain in critical state, which, among other determinants (degradation, erosion, etc.), is explained by the pollution of the latter (Savchenko, Babikov \& Oliinyk, 2017; Swartjes, Carlon, \& DeWit, 2008), which is increasingly viewed as a serious obstacle to sustainable development of the European countries (Gilmore, 2001).

Given the transboundary nature of the soil pollution issue, it is necessary to agree with those experts, who emphasize that there is a clear urgent need for a concerted action aimed at combatting this negative phenomenon within the EU (Rodrigues et al., 2009; Glæsner, Helming \& моделювання. У результаті дослідження притаманних законодавству дев'ятнадцяти країн Європейського Союзу різних моделей кримінально-правової охорони земельних ресурсів доведено, що: 1) така охорона має здійснюватися за допомогою єдиної універсальної норми, присвяченій регламентації кримінальної відповідальності за забруднення не лише земельних ресурсів, а й інших компонентів довкілля (вода, атмосферне повітря, ліс); 2) злочинним має визнається лише таке забруднення земель, яке призвело до реальної (не потенційної) шкоди навколишньому природному середовищу, здоров'ю людини чи майнової шкоди; 3) відповідальність за забруднення земель має бути диференційована залежно від того: а) умисним чи необережним було діяння винної особи; б) які наслідки спричинило забруднення земель.

Ключові слова: довкілля, забруднення, земельні ресурси, злочин, кримінальна відповідальність.

De Vries, 2014). At the same time, despite the scale of such issue, academics state that EU countries still lack a common legislative instrument for their criminal law protection (Valentín, Nousiainen, \& Mikkonen, 2013). This is despite the fact that the EU Directive 2008/99/EU on the application of criminal law to the protection of the environment, adopted in 2008, stated that, on the one hand, effective environmental protection can only be achieved, if there is an effective mechanism for its criminal law protection, and on the other hand - directly pointed to the low effectiveness of such mechanism, which was explained in part by the lack of a coherent policy in this regard (Directive 2008/99/EC). All these circumstances underline the relevance of the topic chosen for research.The structure of the study and its division into relevant sections are based on objective and subjective features of criminal offenses, which provide for liability for criminal pollution of land resources - subject, consequences, guilt, aggravating circumstances. We deliberately did not analyze the elements of the act, since in fact they have been described by a single term "pollution" in all countries studied. Literature Review

Some issues of criminal law protection of land resources have been covered in the works of such researchers as L. Bukalerova \& A. Shveiger, A. (2013); V. Ladychenko, O. Yara, L. 


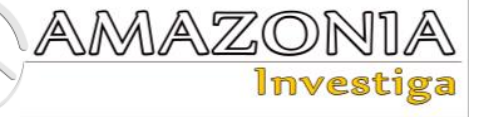

Golovko \& V. Serediuk (2019); Overkovskaya (2021); I. Popov (2012); A. Savchenko, O. Babikov \& O. Oliinyk (2017); Yu. Turlova (2016); F. Comte, L. Kramer, \& O. Dubovik (2010); O. Yara and others (2018). While recognizing the great theoretical and practical significance of research by these scientists, it should be noted that their attention had been mainly focused on studying legislation of specific countries (Eshmurodov, 2020), or on a comprehensive study of criminal liability for crimes against the environment in general (Comte, 2003; Turlova, 2016; Waling, 1994), or only on environmental aspects of the relevant issues (Ladychenko, Yara, Uliutina \& Golovko, 2019; Hollins, \& Percy, 1998; Lisova \& Sharapova, 2020; Meiyappan, Dalton, O’Neill, \& Jain, 2014; Yara, Uliutina, Golovko, \& Andrushchenko, 2018). At the same time no special studies have been made in the legal literature, within which comprehensive analysis of the EU legislation on the introduction of criminal liability for pollution of land resources, though this is a necessary prerequisite for developing optimal legislative model of criminal law response to relevant socially dangerous manifestations.

\section{Methodology}

This research is based on the use of the comparative law method, which has been employed to compare provisions of the criminal law of nineteen EU countries, as well as the EU Council Framework Decision 2003/80/JHA on criminal law protection of the environment of January 23, 2003 (Council Framework Decision) and the EU Directive 2008/99/EC on the application of criminal law to the protection of the environment. Based on the method of systemic analysis, a study of the experience of EU member states in the construction of standards which provide for criminal liability for pollution of land resources has been conducted. The authors used formal-logical method in interpreting the studied norms on liability for crimes in the field of land relations. Furthermore, dialectical method allowed to comprehend the problems of research, its methodological bases, to structure research, to carry out step-by-step knowledge of the object of research. Using the modeling method, the optimal legislative model of criminal law protection of land resources has been elaborated, which can be used when looking for ways to improve EU members' national legislation.

For our study, we have selected EU countries where criminal liability is provided for land pollution. Among them are Austria, Bulgaria, Denmark, Estonia, Spain, Italy, Latvia, Lithuania, Liechtenstein, the Netherlands, Germany, Poland, Portugal, Slovakia, Slovenia, Hungary, Croatia, the Czech Republic, and Sweden. The choice of such a wide range of countries is explained by the proven fact that the study of foreign experience of as many countries as possible contributes to the transposition of relevant provisions of different foreign countries criminal law, their adaptation, convergence, harmonization, unification and so on (Vozniuk, Dudorov, Tytko, \& Movchan, 2020).

\section{Results and discussion}

Elements of the environment subject to criminal protection against pollution (subject). First of all, it should be noted that criminal law of most EU countries contains a single universal prohibition on criminal law protection against pollution of not only land resources but also of environmental components such as water, air and, less frequently, forest (Czech Republic), animals and plants (Estonia), biota - flora and fauna (Hungary). In Lithuania and Slovakia, the list of environmental components protected from pollution is not specified, and the term "natural resources" is used instead. Only laws of Liechtenstein and Germany contains separate norms, which deal exclusively with the pollution of lands and, more precisely, soils. 
Table 1.

Elements of the natural environment protected by law (developed by the authors)

\begin{tabular}{ll}
\hline Country & Object of criminal violation \\
\hline Austria & land, water, air \\
Bulgaria & land, water, air \\
Denmark & land, water, air, soil \\
Estonia & soil, water, air, animals, plants \\
Spain & earth, subsoil, air, water \\
Italy & soil, subsoil, water \\
Latvia & land, subsoil, water, forest \\
Lithuania & natural resources \\
Liechtenstein & Soil \\
Netherlands & land, water, air \\
Germany & Soil \\
Poland & soil, water, air \\
Portugal & land, water, air \\
Slovakia & natural resources \\
Slovenia & land, water, air \\
Hungary & land, air, water, biota (flora and fauna) \\
Croatia & land, soil, water, sea, air \\
Czech Republic & soil, water, air, forest and other components of the environment \\
Sweden & land, water, air \\
\hline
\end{tabular}

In our opinion, given the organic relationship of all these types of natural resources, there is no need to differentiate criminal liability for pollution of each of them. This view is supported by L. Bukalerova and O. Schweiger, who point out that the essence of pollution should be reduced to the consequences of a onedimensional nature and the delimitation of norms on environmental objects is impractical, since it does not take into account all possible consequences for a particular object (Bukalerova \& Shvejger, 2013).

Consequences. Depending on the peculiarities of constructing the consequences element of the discussed provisions, the approaches of the parliamentarians of the EU countries to the presentation of the studied norms can be divided into three groups:

1) In the so-called first group of countries, any pollution, which has created a danger to human life or health or the environment (torts of danger) is considered criminally illegal;

2) In the second group - only pollution which led to the occurrence of real socially dangerous consequences, which are provided for in the dispositions of the relevant criminal law provisions;

3) Legislators of the third group of countries apply a comprehensive approach, when the condition of recognizing pollution as criminal are both real consequences and the threat of their occurrence.

Table 2.

Division of provisions depending on the consequences related to criminal liability for pollution of land resources (developed by the authors)

\begin{tabular}{ll}
\hline Country & Consequences of pollution \\
\hline \multirow{3}{*}{ Austria } & - endangering life or health of a large number of people or; \\
& - creating a significant danger to the state of fauna or flora or; \\
& - long-term deterioration of water, soil or air quality or; \\
& - cases when the cost of eliminating pollution exceeds 50 thousand euros \\
& - creating danger to humans, animals and plants, or; \\
Bulgaria & - making natural resources unsuitable for use in cultural and domestic, health, agricultural and \\
& other economic purposes \\
Denmark & - causing significant damage or; \\
& - creating a real danger of causing significant damage to the environment \\
Estonia & - creating a danger to human life or health or; \\
& - creating a risk of significant damage to the quality of water, soil or air, animals or plants or \\
Spain & parts thereof \\
\hline
\end{tabular}




\begin{tabular}{|c|c|}
\hline Italy & - pollution \\
\hline Latvia & $\begin{array}{l}\text { - causing significant damage to the environment, human health, property or economic } \\
\text { interests }\end{array}$ \\
\hline Lithuania & $\begin{array}{l}\text { - creating a threat of significant damage to air, land, water, animals or plants or other serious } \\
\text { consequences for the environment }\end{array}$ \\
\hline Netherlands & $\begin{array}{l}\text { - creating a threat to public health or life of another person, death of a person } \\
\text { - causing harm to the health of another person, animals, plants or other objects of value, or }\end{array}$ \\
\hline Germany & $\begin{array}{l}\text { water bodies, or; } \\
\text { - significant pollution or other negative impact on the environment }\end{array}$ \\
\hline Poland & $\begin{array}{l}\text { Contamination in such quantity or in such a form that it can: } \\
\text { - endanger human life or health, or; } \\
\text { - cause a significant decrease in the quality of water, air or land surface, or; } \\
\text { - cause damage to flora or fauna on a large scale }\end{array}$ \\
\hline & $\begin{array}{l}\text { causing significant damage, which should be understood as such losses that: } \\
\text { - significantly or permanently impair the physical integrity and well-being of people, or; } \\
\text { - make it impossible to use the environmental component for a long time, or; }\end{array}$ \\
\hline Portugal & $\begin{array}{l}\text { - have led to the spread of microorganisms or substances harmful to the body or health of } \\
\text { people, or; }\end{array}$ \\
\hline & $\begin{array}{l}\text { - had a significant impact on the conservation of species or their habitats, or; } \\
\text { - significantly worsened the quality or condition of the environmental component }\end{array}$ \\
\hline Slovakia & $\begin{array}{l}\text { - creating a threat of damage to the environment } \\
\text { - creating a threat to the life of one or more persons, or; }\end{array}$ \\
\hline Slovenia & $\begin{array}{l}\text { - causing serious harm to the quality of air, soil or water, as well as to animals or plants, or; } \\
\text { - creating a danger of significant deterioration of the habitat in the protected area }\end{array}$ \\
\hline Hungary & - endangering natural resources \\
\hline Croatia & $\begin{array}{l}\text { - creation for a long period of time or to a large extent of a threat to the quality of natural } \\
\text { resources, or; } \\
\text { - creating a threat to natural resources over a vast territory, in which animals, plants, or human } \\
\text { life or health are endangered }\end{array}$ \\
\hline Czech Republic & $\begin{array}{l}\text { - significant damage to soil or a threat to it, of water, air, forest or other component of the } \\
\text { environment, or; } \\
\text { - pollution of natural resources that could cause serious harm to health or death, or; } \\
\text { - if it requires significant costs to eliminate the consequences of such behavior, or; } \\
\text { - a person intentionally increases such damage or threat to an environmental component or } \\
\text { aggravates its rejection or mitigation }\end{array}$ \\
\hline Sweden & $\begin{array}{l}\text { - pollution which is insignificantly harmful to human health, animals or plants, or; } \\
\text { - any other significant violation of the environmental rules }\end{array}$ \\
\hline
\end{tabular}

In our opinion, construction of the analyzed provision as a tort of creating a danger is not justified. In particular, I. Popov suggests that responsibility for creating a threat of pollution and the lack of precise criteria for the crime of acts leads to the fact that, for example, tens of thousands of crimes against the environment are registered in Germany each year (Popov, 2012) (among the latter the average share of soil pollution is about 10\%) (Comte, Kramer, \& Dubovik, 2010). We believe that, given the prevalence of environmental pollution (including land resources), only those, which have led to real socially dangerous consequences should be recognized as criminally unlawful.

In this respect, the experience of Latvia deserves the most attention, in which only land pollution, which has led to significant damage to the environment, human health, property or economic interests (Part 2 of Article 102 of the Criminal Code of Latvia (1998)) is considered criminal. As one can see, despite the fact that the relevant act was considered a crime against the environment, in addition to damage to the environment, Latvian parliamentarians also found the pollution that led to real damage to human health and property to be criminal. At the same time, we note that for the reason of a unified interpretation of the relevant provisions of criminal law in Art. 102 of the Criminal Code of Latvia (1998) should have fixed a specific indicator of "significant damage to property or economic interests." In particular, this is the path taken by the Austrian legislator, which clearly states in Articles 180-181 of the Criminal Code of Austria (1974) that only such pollution should be punished by criminal law, the cost of eliminating which exceeded 50 thousand euros.

Guilt. Two approaches are used in presenting the characteristics of the subjective side of the discussed criminal offenses in the EU member states: 1) differentiated and 2) unified.

A differentiated approach involves delineating liability for land pollution depending on whether it was done intentionally or negligently. For example, in comparison the Austrian Criminal Code (Criminal Code of Austria, 1974) provides 
for imprisonment for up to three years for intentional contamination of natural resources $(\S$ 180 ) and only up to one year for negligent contamination (\$181). Under the German Criminal Code, the penalty for intentional soil contamination is imprisonment for up to five years or a fine (Part 1, §324-a), and for negligence - up to 3 years or a fine (Part $3, \S 324$ a) (Criminal Code of Germany, 1998).

It should be also noted that such differentiated approach, in turn, also has two options: in some countries, differentiation occurs within certain parts of one article, while in others - in different articles of criminal law.

Instead, legislators in countries, which use a unified approach, have not considered it appropriate to delineate liability based on whether the pollution was intentional or negligent.

Table 3.

Division of EU countries based on whether their criminal law differentiates liability for land pollution depending on the form of guilt (developed by the authors)

\begin{tabular}{|c|c|c|c|}
\hline Liability is differentiated & & & Liability is unified \\
\hline & Willfulness & Negligence & \\
\hline Austria & Art. 180 & Art. 181 & Denmark \\
\hline Bulgaria & $\begin{array}{l}\text { Part } 1 \text { and } 3 \text { of Art. } \\
352\end{array}$ & Part 4 of Art. 352 & Spain \\
\hline Estonia & Art. 364 & Art. 365 & Italy \\
\hline Liechtenstein & Part 1 of Art. 89 & Part 2 of Art. 89 & Latvia \\
\hline Netherlands & Art. $173-\mathrm{a}$ & Art. 173-b & Lithuania \\
\hline Germany & Part 1 of Art. 324-a & Part 3 of Art. 324-a & Sweden \\
\hline Poland & Part 1 of Art. 182 & Part 2 of Art. 182 & \\
\hline Portugal & $\begin{array}{l}\text { Part } 1 \text { and } 2 \text { of Art. } \\
279\end{array}$ & $\begin{array}{l}\text { Part } 4 \text { and } 5 \text { of Art. } \\
279\end{array}$ & \\
\hline Slovakia & Art. 300 & Art. 301 & \\
\hline Slovenia & Part 1 of Art. 332 & Part 4 of Art. 332 & \\
\hline Hungary & Part 1 of Art. 241 & Part 2 of Art. 241 & \\
\hline Croatia & Part 1 of Art. 193 & Part 3 of Art. 193 & \\
\hline Czech Republic & Chapter 293 & Chapter 294 & \\
\hline
\end{tabular}

When assessing the benefits of these approaches, it is important to keep in mind justice as a feature of criminal law. The principle of justice is key to criminal law, the law must be based on it, and not the other way around: what is just is lawful. One of the components of justice is that intentional crime should be punished more severely than a negligent crime.

If we take into account the above-mentioned to return to the issue of criminal law protection of land from pollution, it should be noted that, for example, actions of a dump truck driver who, while being clearly aware of the public danger of his actions, throws waste in order to save time and money, on the one hand, and actions of a person who, due to negligence in his responsibilities, caused pollution or damage to land, on the other hand, cannot be viewed as equally socially dangerous (Dudorov \& Movchan, 2020).
Qualifying features. As it turned out, the question of the expediency of allocating qualified crime sets within the framework of the considered criminal law norms is resolved differently among the EU countries: in some countries liability for any means of land pollution is unified, while in others it is differentiated depending on the consequences. At the same time, the increase in liability for land pollution is most often associated with the occurrence of two such socially dangerous consequences as human death or other serious damage to health and significant (significant, large, long-term recovery) damage to the environment as a whole or its individual components. Less often, differentiation is associated with such features as contamination with hazardous substances (Italy), its commission for selfish motives or for the purpose of making a large profit (Germany, Czech Republic), the recurrence of the relevant offense (Czech Republic).

Table 4. 


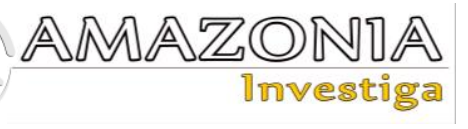

Nations, which criminal law provides for qualifying elements of land (or other natural resources) contamination (developed by the authors)

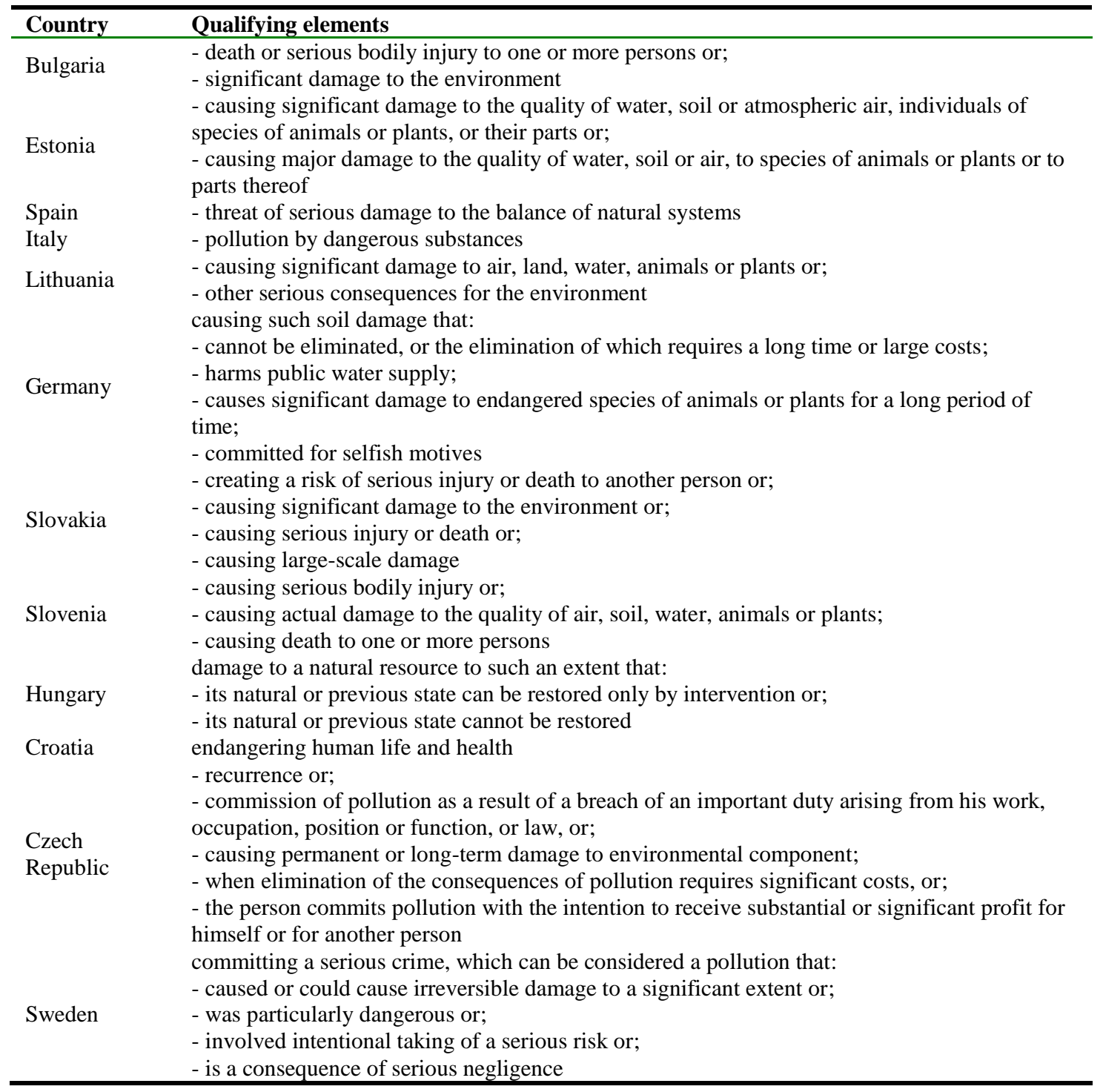

Reflecting on the abovementioned approaches, we would like to recall again that in criminal law it is recognized fair and therefore legitimate to apply a more severe punishment: for encroachment on a more valuable object; for an intentional crime compared to a negligent one; an act which caused significant damage compared to an act which caused less dangerous consequences; acts committed in complicity, compared to crimes committed alone, etc. According to European commentators, penalties for environmental pollution must be effective, proportionate and convincing (Proposal). Taking into account these general theoretical provisions, we came to the conclusion that the approach of the legislators of those countries, in which differentiated liability depends on the consequences of land pollution, deserves support. After all, it cannot be considered fair to impose the same punishment, for example, for land pollution, which has not led to any socially dangerous consequences and similar manifestations that have led to the death of one or more people, or for land pollution, which environmental consequences are minimal, and actions that have led to the pollution of a large area of land, disappearance or significant reduction of the population of animals or plants, pollution of water sources, etc.

\section{Conclusion}

Legal liability is a significant element of the legal regulation of public relations aimed at influencing the behavior of individuals through legal measures; its goal is to protect and defend public relations from any illegal violations 
through coercive measures (Minchenko et al., 2021).

Based on the results of a comparative study of the criminal law of nineteen European Union member states, it can be concluded that the optimal legislative model of criminal law protection of land resources provides for the creation of a single universal rule:

1) which will be devoted to the regulation of criminal liability for pollution not only of land resources but also of other components of the environment (water, air, forest);

2) in which only such land pollution which has led to real (non-potential) damage to the environment, human health or property damage is considered criminal. In such case, these consequences should be as formalized as possible, which, in particular, can be ensured by indicating the specific amount of property damage, in the event of which pollution is considered criminally illegal;

3) within which liability for land pollution will be differentiated depending on:

a) whether an act by guilty person was intentional or negligent;

b) what the consequences of land pollution have been.

At the same time, we agree with scholars who emphasize that mere criminalization of land pollution and improvement of relevant substantive criminal law cannot significantly improve situation in the field of land protection, because even in the presence of relevant norms a state (represented by law enforcement agencies) may do little or nothing to apply these rules in practice (Faure, 2017), in particular, refusing to investigate the identified facts of land pollution. Therefore, solving the problem of land protection from pollution requires the application of a comprehensive approach aimed at improving the rules of not only criminal but also environmental, administrative, criminal procedure law and so on.

\section{References}

Bukalerova, L., \& Shveiger, A. (2013) Criminal and legal protection of nature from pollution: international and foreign aspects. Moscow University Bulletin named after S. Yu. Witte. Series 2: Legal Sciences, 2, 51-59.

Comte, F. (2003). Criminal Environmental Law and Community Competence. European Environmental Law Review, 5, 147-156. Retrieved from https://papers.ssrn.com/sol3/papers.cfm?abstract_i $\mathrm{d}=2701677$
Comte, F., Kramer, L. \& Dubovik, O. (2010) Environmental Crime in Europe. Moscow: Gorodets Publishing House. http://lawlibrary.ru/izdanie2126219.html Council Framework Decision No. 2003/80/JHA, On the protection of the environment through criminal law. Official Journal of the European Union. Brussels, Belgium, January 27, 2003. Retrieved from http://eurlex.europa.eu/LexUriServ/LexUriServ.do?uri=CE LEX:32003F0080:EN:HTML

Criminal Law of the Republic of Latvia. Zinotajs. Riga, Latvia, June 17, 1998. Retrieved from https://www.legislationline.org/download/id/9122/ file/Latvia_Criminal\%20Code\%20as\%20of\%2020 20.pdf

Directive of the European Parliament and of the Council No. 2008/99/EC, On the protection of the environment through criminal law. Strasbourg, France, November 19, 2008. Retrieved from https://eur-lex.europa.eu/legalcontent/EN/TXT/?uri=CELEX\%3A32008L0099

Dudorov, O., \& Movchan, R. (2020). About directions of improvement of the mechanism of criminal and legal protection of environment (on a note to developers of the new Criminal code of Ukraine). Bulletin of the Association of Criminal Law of Ukraine, 1, 92-125. Retrieved from http://vakp.nlu.edu.ua/article/view/204733.

Eshmurodov, E. (2020). Issues Of Criminal Liability For Violation Of The Requirements Of The Law On Ecology And The Environment. The American Journal of Political Science Law and Criminology, 2(11), 93-98. Retrieved from https://usajournalshub.com/index.php/tajpslc/articl e/view/1462/1394

Faure, M. (2017). The Development of Environmental Criminal Law in the EU and its Member States. Review of European Community \& International Environmental Law, RECIEL 26 (2), 139-146.

Federal Law of Austria No. 60/1974, Criminal Code of the Republic of Austria. Federal Laws Bulletin. Vienna, Austria, January 23, 1974. Retrieved from https://www.legislationline.org/download/id/8548/ file/Austria_CC_1974_am122019_de.pdf

Federal Law of Germany, German Criminal Code. Federal Law Gazette, Berlin, Federal Republic of Germany, November 13, 1998. Retrieved from https://www.gesetze-im-

internet.de/englisch_stgb/englisch_stgb.pdf

Gilmore, E. (2001). A Critique of Soil Contamination and Remediation: The Dimensions of the Problem and the Implications for Sustainable Development. Bulletin of Science, Technology \& Society, 21 (5), 394-400.

Glæsner, N., Helming, K., \& De Vries, W. (2014). Do current European policies prevent soil threats and support soil functions? Sustainability, 6 (12), 9538-9563. 


\section{AMAZONIA
Dnvestiga}

Hollins, M., \& Percy, S. (1998). Environmental Liability for Contaminated Land: Towards a European Consensus. Land Use Policy, 15 (2), 119133.

Ladychenko, V., Yara, O., Golovko, L., \& Serediuk, V. (2019). Groundwater management in Ukraine and the EU. European Journal of Sustainable development, 8(1), 31-39. Retrieved from

http://www.ecsdev.org/ojs/index.php/ejsd/article/v iew/763/758

Ladychenko, V., Yara, O., Uliutina, O., \& Golovko, L. (2019). Environmental Liability in Ukraine and the EU. European Journal of Sustainable Development, 8(2), 261-267. Retrieved from http://ojs.ecsdev.org/index.php/ejsd/article/view/8 $10 / 805$

Lisova, T., \& Sharapova, S. (2020). Legal issues of protection of agricultural land in Ukraine at the present stage. Amazonia Investiga, 9(27), 209$216 . \quad$ Retrieved from https://amazoniainvestiga.info/index.php/amazonia /article/view/1229

Meiyappan, P., Dalton, M., O’Neill, B.C., \& Jain, A.K. (2014). Spatial modeling of agricultural land use change at global scale. Ecological Modelling, 291, 152-174. Retrieved from https://www.sciencedirect.com/science/article/pii/ S0304380014003640

Minchenko, R., Lutsyuk, P., Kamensky, D., Kolodin, A., \& Shamota, O. (2021). Civil and criminal liability in the field of transport relations: the impact of the Covid-19 pandemic. Amazonia Investiga, 10(40), 212-221. Retrieved from https://amazoniainvestiga.info/index.php/amazonia /article/view/1613

Overkovskaya, T. (2021). Legal regulation of management in the field of use and land protection. Colloquium-journal, 16(103), 47-53. Retrieved from

http://repository.vsau.org/repository/getfile.php/28 678.pdf

Popov, I. (2012). Responsibility for crimes against the natural environment under the legislation of the Federal Republic of Germany. International research journal, 10, 103-106. Retrieved from http://research-journal.org/law/otvetstvennost-zaprestupleniya-protiv-prirodnoj-sredy-pozakonodatelstvu-frg/

Proposal No. 52006PC0232, Proposal for a Directive of the European Parliament and of the Council establishing a framework for the protection of soil and amending Directive 2004/35/EC /* COM/2006/0232 final - COD 2006/0086 */. Bulletin of the European Union, Brussels, Belgium, September 22, 2006. Retrieved from https://eur- lex.europa.eu/legalcontent/EN/TXT/?uri=CELEX\%3A52006PC0232 Rodrigues, S. M., Pereira, M. E., da Silva, E. F., Hursthouse, A. S., \& Duarte, A. C. (2009). A review of regulatory decisions for environmental protection: Part I - Challenges in the implementation of national soil policies. Environment International, 35 (1), 202-213.

Savchenko, A., Babikov, O. \& Oliinyk, O. (2017). Comparative and Legal Analysis of Criminal and Legal Protection of Individual Components of Natural Environment: European Experience. Journal of Advanced Research in Law and Economics, 8 (7), 2209-2216.

Swartjes, F. A., Carlon, C. \& de Wit, N. H. (2008). The possibilities for the EU-wide use of similar ecological risk-based soil contamination assessment tools. Science of the Total Environment, 406 (3), 523-529.

Turlova, Yu. A. (2016). The system of environmental crimes. Uzhhorod National University Herald. Series "Law”, 2(36), 103 $109 . \quad$ Retrieved from https://dspace.uzhnu.edu.ua/jspui/bitstream/lib/281 39/1/\%D0\%A1\%D0\%98\%D0\%A1\%D0\%A2\%D0 $\% 95 \% \mathrm{D} 0 \% 9 \mathrm{C} \% \mathrm{D} 0 \% 90 \% 20 \% \mathrm{D} 0 \% 95 \% \mathrm{D} 0 \% 9 \mathrm{~A} \%$ D0\%9E\%D0\%9B\%D0\%9E\%D0\%93\%D0\%86\% D0\%A7\%D0\%9D\%D0\%98\%D0\%A5\%20\%D0\% 97\%D0\%9B\%D0\%9E\%D0\%A7\%D0\%98\%D0\%9 D\%D0\%86\%D0\%92.pdf

Valentín, L., Nousiainen, A., Mikkonen, A. (2013) Introduction to Organic Contaminants in Soil: Concepts and Risks. In: Vicent, T., Caminal, G., Eljarrat, E., Barceló, D. (eds) Emerging Organic Contaminants in Sludges. The Handbook of Environmental Chemistry, vol 24. Berlin, Heidelberg: Springer,

Vozniuk, A., Dudorov, O., Tytko, A., \& Movchan, R. (2020). Implementation of UN and EU recommendations on criminalization of organized crimes. Amazonia Investiga, 9 (28), 234 $240 . \quad$ Retrieved from https://amazoniainvestiga.info/index.php/amazonia /article/view/1307

Waling, C. (1994). Crimes against the Environment. International Review of Penal Law, 1065, 1080-1082.

Yara, O., Uliutina, O., Golovko, L. \& Andrushchenko, L. (2018). The EU Water Framework Directive: Challenges and Prospects for Implementation in Ukraine. European Journal of Sustainable development, 7(2), 175-182. Retrieved from http://www.ecsdev.org/ojs/index.php/ejsd/article/v iew/649/645 